\title{
Creation, Kinds and Destiny: A Christian View of Genome Editing
}

\section{Trevor Stammers ${ }^{1}$}

Men ought not to play God before they learn to be men, and after they have learned to be men they will not play God (Paul Ramsey, Fabricated Man: The Ethics of Genetic Control, 138)

The discovery of the double helix structure of DNA by Crick, Franklin and Watson in 1953 caused a paradigm shift in our understanding of the nature of both humankind and creation as a whole. Subsequently in 2003, the mapping of the human genome by Frances Collins and his colleagues and the ensuing development of techniques to alter it, raise fundamental questions about our destiny - whether we ourselves can and should shape it in a way previously outside our ability and known only to God.

The Christian understanding of the Fall - the movement of humanity from an initial state of perfection or at least of being 'very good' (Genesis 1v 31) in God's sight, to a state of obvious imperfection - has always raised questions of normalcy in relation to our current 'fallen' state compared to what was originally intended by the Creator. This paper explores Christian visions of the ethical possibilities of genome editing using Bonhoeffer's understanding of the nature of the material world and the effects of the Fall upon it as a model and continues with an exploration of wider implications of other elements of the creation account.

It will be argued that, far from supporting the popular understanding of genetic determinism with its implications for the concepts of both free will and human responsibility, our greater knowledge of genomics weakens such a determinist view. The paper concludes with a consideration of the telos of humanity in relation to gene editing and an examination of the concept of the

1 Reader in bioethics at St. Mary's University, Twickenham, London and Director of its Centre for Bioethics and Emerging Technologies, trevor.stammers@stmarys.ac.uk

(C) TREVOR STAMMERS, 2019 | DOI:10.1163/9789004392137_010

This is an open access chapter distributed under the terms of the prevailing CC-BY-NC License at the time of publication. 
genome as a 'secular soul' and the religious elements of the genomic editing quest.

\section{Origins: Creation and Fall}

Christianity has its roots inextricably embedded in the Old Testament. Jesus either quotes from or refers to it, dozens of times in the Gospel accounts. On one such occasion, when responding to a question about divorce (Matthew 19:4-6, Mark 10:6-8), Christ quotes from the Genesis creation account to answer his critics. The creation narrative plays a key role in the New Testament and in Christian theology as a whole so I begin here with an overview of the 2oth century theologian, Dietrich Bonhoeffer's understanding of Creation and Fall in his 1937 work of that title, as an example of Christian understanding of the nature of the world which emerges from the Genesis accounts.

\section{Bonhoeffer on Creation}

Bonhoeffer, writing of course prior to the discovery of DNA but post-Darwin, highlights several important elements of Creation according to Genesis. Firstly, God is distinct from his creation; the creation is not a fragment of God. He does not give birth to the universe but speaks it into being. He creates by his word alone. "God is never in the world in any way except in his absolute transcendence of it" (Bonhoeffer 1937, 19).

So God speaks creation into being and sees that every element of it is 'good' (Genesis 1V25) or 'very good' (Genesis 1v31). Now Bonhoeffer immediately stresses that this does not mean, "that the world is the best of all conceivable worlds. It means that the world lives completely in the presence of God, that it begins and ends in him and that he is Lord" $(1937,22)$. Furthermore that "which is created by the Word out of nothing, that which is called forth into being, remains sustained by the sight of God" $(1937,23)$. God does not wind up the universe like a clock and leave it to tick on of its own accord; rather as the New Testament has it, "he holds all creation together" (Colossians 1v17) and "he sustains all things by his powerful word" (Hebrews 1v3).

God also speaks life into being. - plants and vegetation, sea life, birds and land animals, all 'according to their kind' (Genesis 1v14). Even so, Bonhoeffer reminds us "It is not the Creator's own nature which he here instils in the living and life-creating. The living and creative is not divine: it is and remains the creaturely" $(1937,34)$. However when it comes to the creation of humankind, there is another element involved. "Only in something that is itself free can the One who is free, the Creator, see himself" $(1937,34)$ comments Bonhoeffer. 
"If the Creator wills to create in his own image, he must create it in freedom; and only this image in freedom would fully praise him and fully proclaim the honour of its Creator" $(1937,34)$.

So we read that God does indeed create humankind in his own image, male and female, from the dust of the earth. The human body is fashioned out of earth just as the earth gave rise to other animals but God breathes his life uniquely into this creature and man becomes 'a living soul' (Genesis 2v7). Humans alone are created in the 'image of God' - the imago dei.

There are many contemporary theologians who attempt to play down the importance of the imago dei. "The actual meaning of 'image of God' has varied so much during Christian history that no clear, single reference emerges and it seems to mean what people want it to mean." (Page 2003, 71) Much the same could be said however of the breadth of meaning of many other terms such as 'human dignity' or 'autonomy' but it may well be this relates to the richness of meaning of these concepts rather than implying they have no meaning at all.

Bonhoeffer for example, singles out two prime elements of what it means to be 'in the image of God'; firstly that it means to be free and in particular, free to worship the Creator and secondly that it is mankind who has the delegated authority of God to rule over creation in responsible way. "I belong to this world completely. It bears me, nourishes, and holds me. But my freedom from it consists in the fact that world to which I am bound ...is subjected to me and that I am to rule over [it]" (Bonhoeffer 1937, 78).

How does this very brief synopsis of Bonhoeffer's view of the creation narratives tie in with our contemporary knowledge of genomics? Surprisingly well in my view. The account emphasizes firstly, that all living things, including human beings, are created out of the earth. The fact then that the Human Genome Project (HGP) has shown us that there is similarity between the DNA of all species is no challenge to belief in a Creator. For some people, however, genomic similarity appears problematic in this regard. "Perhaps this is an unwelcome challenge to our opinion of ourselves. As humans we have long regarded ourselves as the pinnacle of creation" (Seller 2003, 340). Perhaps so, but the Bible certainly does not encourage us to have too high an opinion of ourselves (Romans 12v3) and in any case it is our ability to commune with our Creator that makes us special and not our genome per se. It should therefore not be a concern to us that as a species we share $50 \%$ of our DNA with a banana and over $98 \%$ with a chimpanzee (O'Connell 2009). We came from the same clay after all.

Secondly, our physical embodied form is affirmed along with the rest of creation as being very good. It is not a mistake that we have bodies just as other animals do but rather this is God's intention. Therefore we are not to regard our 
bodies as a prison from which to escape but as a 'temple of God' (I Corinthians $3 \mathrm{vi} 6,6 \mathrm{vig})$, through which we are to live for his worship and praise. Our bodily well being is therefore important and we have good reason to use wisely our knowledge of what makes it healthy, including the new possibilities arising from genomics.

Thirdly, however, the creation account gives clear indications that despite our material similarities with the rest of living things, we are different. Christians, along with those of other faiths which believe humanity has a special relationship to God being made in his image in a way like no other creature, have no option but to be 'guilty' of speciesism. Not because we believe other species should be treated in any way we like - there are many scriptural warnings against inhumane treatment of animals (e.g. Deut 25v4; Proverbs 12v10; I Timothy $5 \mathrm{v} 18$ ) - but because we alone have the freedom to rule over and care for the rest of creation by virtue of being made in God's image and receiving his delegated authority to do so (Genesis 1v26; 2v15). How this might be rightly exercised in regard to genomic editing can only however be considered after taking into account the reality of the Fall.

\section{Bonhoeffer on the Fall}

Though as we have seen, for Bonhoeffer a key element of being made in the image of God is the reality of our human free will, we are not entirely free to do as we please. God also sets a limit on that freedom with a prohibition that Adam and Eve were to adhere to, in the form of a tree from which they were not to eat (Genesis 2v17). Adam "who is addressed as one who is free, is shown this limit, that is to say his creatureliness, and by this prohibition is his being confirmed in its kind" (Bonhoeffer 1937, 51). That is to say that Adam, though in the image of God, is not God; temptation comes to him in due course in the voice of the serpent instilling first doubt - "Has God said", then denial - "you shall not die" and finally defiance- "God knows when you eat it your eyes will be opened and you will be as God" (Genesis 3v4).

Bonhoeffer sees the Fall as a rejection of contentment with the imago deibeing in the image of God-resulting in an attempt to be as or like God - sicut deus. Prof. Neil Messer puts it like this "The attempt to be 'like God'...springs from a forgetfulness or denial of our creaturely limits, an assumption we can and may do anything we choose. The problem with projects done in this spirit is not so much the prospect of failure... as the price of success." (Messer 2011, 38-39). The price of success for Adam is the ultimate one, as Bonhoeffer explains: "It is true that man becomes sicut deus through the fall but this very sicut deus can live no longer; he is dead" (1937, 70-71). Alienated from God by disobedience, Adam reaps the bitter consequences of human shame (Genesis 
3v7) and banishment from the presence of God (Genesis 3v23). Not only does mankind undergo spiritual death - separation from God, the earth too from which humanity was fashioned is also cursed (Genesis 3v17). "All other creatures rise up against sicut deus man, the creature that tries to live out of his own self ....since they are subject to man, they fall with the Fall of man. Nature is without a lord and therefore it is itself rebellious and desperate" (Bonhoeffer 1937, 87).

In the light of Bonhoeffer's analysis, one of the ways in which we might attempt to discern between the ethically permissible and impermissible in bioengineering projects, including genome editing, is to look at whether they are appropriate for us to undertake as creatures made in God's image or whether they extend our attempts to usurp God's place and to be like him. Making this distinction however is rarely easy but may be helped by exploring a number of other key debates in bioethics related to genome editing to which I now turn.

\section{Identity, Healing and Enhancement}

"It is a profound misunderstanding of the human condition to think we can optimise ourselves in such a way that all human suffering is abolished", insists Prof Maureen Junker-Kenny $(2003,127)$. Most reflective healthcare professionals intuitively recognise this to be true. As a physician for over thirty years, I would reckon that around a half of the suffering I encountered in my patients in general practice was existential, rather than stemming from disease. The grief of parents whose son was murdered, the heartache of a mother whose son had not spoken to here for decades are just two specific examples of the two main general areas of suffering highlighted by Junker-Kenny $(2003,126)$, firstly the consciousness of human finitude, the awareness that we will die and secondly the heartache of unrequited recognition by others which can never be eased by ourselves but only in the response of others to us, which we cannot control no matter how 'perfect' our genome 'is. It is not good to be alone' (Genesis 2v18) is the first thing in the creation account that God declared was not good. Our relationships with others remain a fundamental human need in spite of all our technological advances.

\section{The Medical Model of Health}

Though questions about how we define health, disease and normalcy have long been a source of debate, the advent of genome editing has undoubtedly given them a new urgency. The medical model, championed amongst others by Boorse, seeks to confine such definitions within supposed objective sci- 
entific parameters. Disease is a state that "interferes with the performance of some natural function...characteristic of the organism's age" and becomes an "illness only if it is serious enough to be incapacitating" (Boorse 1976, 61).

This model of understanding of health is the one within which gene editing has already achieved early success which is likely to accelerate. However Prof. Richard Hare has raised several problems posed by the medical model. Firstly he suggests that our intuitive understanding of disease and illness is that they are bad for us to have. Boorse therefore has to rely on a "the rather wobbly notion of natural function" (Hare 1986, 178) in order to avoid the intrinsic evaluative element of 'badness' we all have.

Once Hare's evaluative element is allowed however, two other important variables arise:

1) who is making the evaluation? An adult with Down's syndrome for example, may view Down's in a very different light from the clinical geneticist advising a couple at high risk of the condition in their children

2 ) on what grounds are they making it? An autistic adult may find the condition per se distressing or they may not consider autism 'bad' for them but rather the social difficulties associated with it.

These questions are already important in the light of genetic screening but they will become even more so should genomic editing advance as predicted. Eliminating 'abnormality' is already a reality (which will accelerate further with increasingly efficient means of detection of Down's) but it is debatable as to whether this has made or will make for a healthier society.

\section{Views of Creation: Augustine and Wyatt}

If the medical model of health provides too narrow an understanding of disease, the well-known World Health Organisation definition of "Health is a state of complete physical, mental and social well-being and not merely the absence of disease or infirmity" (World Health Organisation 1948) arguably offers far too wide a concept of health.

Eliding health and well being in this way leads to the expectation that social disorder can also be eliminated through medical means. As Messer has pointed out in relation to genome editing, "this understanding would eliminate the distinction between genetic therapy and enhancement and would encourage us to use genetic manipulation...to address any kind of social ill" $(2003,102)$. Furthermore this would necessitate labelling social dissidents as "sick" and coercion rather than compassion might become the response to sickness as a whole - a 'tyranny of health' to use Callahan's striking phrase $(1973,77)$ 
Even so the distinction between therapy and enhancement is not easy to draw. Varying Christian attempts to do so originate from different interpretations of the creation and fall narratives throughout church history. Augustine of Hippo (AD 354-430) in his City of God explicates the fall as entailing the ruin of all humanity (as the offspring of Adam) from a state of perfection by Adam's sin of disobedience. Augustine draws not only on the Genesis account but also St Paul's exposition of it in his letter to the Romans (Chap 5v12-20). This Augustinian schema underpins Prof John Wyatt's analogies of the restored masterpiece and the Lego kit, to attempt to differentiate medical therapy from enhancement.

According to Wyatt, "Our bodies do not come to us value free. They are instead wonderful, original artistic masterpieces which reflect the meticulous design and order imposed by a Creator's will and purpose" (2009, 98). This original masterpiece has however become defaced and flawed by the effects of the fall and Wyatt contends that the task of medicine from a biblical anthropological perspective is to renew the body back to the Creator's original intentions, just as an art restorer does in her work on a painting. This is what therapy entails. It does not preclude the use of innovative technology but the purpose is always to restore to the original.

Wyatt contrasts to this what he dubs the Lego kit view of humanity, which is very different. "There is no right or wrong way to put the pieces together. There is no masterplan from the designer. There is no ethical basis of Lego construction. You can do what you like. In fact, as the advert says "The only limit is your imagination"' (2009, 35). Furthermore, since there is no natural order within a random, mechanistic view of humanity, the difference between natural and enhanced becomes obliterated completely.

\section{Views of Creation: Irenaeus and Cole-Turner}

The flawed masterpiece half of Wyatt's analogy depends on the Augustinian view of the state of original perfection. A different view from Augustine's however was taken by an earlier Christian theologian, Irenaeus (130-202 AD). Both Augustine and Ireneaus considered that mankind fell and is hence in need of redemption. However the Irenaean view on creation is that it is still a work in progress. The first stage of creation - that of being 'in the image of God' is complete. However in this stage humanity is not mature. For Irenaeus, the command to 'be fruitful and multiply' (Genesis 1v28) implies future growth and development, as he explains in Against Heresies (4.11.1). He thus understands the description of Adam and Eve as 'naked and unashamed' (Genesis 2v25) to refer not to complete unawareness of shame in a sinless state but rather to their prepubescence. Hence according to Ireneus (Against Heresies 4.11.1 and 
4.38), God made Adam good but immature so the second stage of creation requires us to grow into the likeness of God by exercising our free will, which includes the possibility of choosing evil.

Thus for Irenaeus, God's declaration of his creation as 'very good' did not mean the world was free from pain and suffering but that it was perfectly suited to God's purpose of developing us into his likeness. Ironically the very thing that constitutes the essence of sin in Bonhoeffer's view - mankind seeking to be like God - becomes the very purpose of God for mankind in Irenaean thought. For Irenaeus, "Adam and Eve could not have been morally and spiritually mature because it is in the very nature of such maturity that it cannot happen apart from over the course of a lifetime of moral choices and experiences" (Schneider 2012: 165).

It is this model of the Irenaean Adam that has proven very attractive to many contemporary theologians as a path to reconciling the Genesis accounts not only with Darwinian evolution but also with more modern evolutionary theories derived from the mapping of the human genome such as that, for example of a group of scientists who, from comparing mitochondrial DNA of many races, conjectured that all humans are descended from one female living in Africa about 240,00o years ago and appropriately called "Eve" (Cann et al. 1987). But aside from its possible implications concerning human origins, the Irenaean account also leads to a very different moral viewpoint from that of Wyatt on the scope of genetic engineering. Such a view is exemplified in the work of Prof Ronald Cole-Turner.

Cole-Turner sees gene editing and synthetic biology having a naturally legitimate role for mankind as partners with God in co-creating our own development. "At the very least, the question of the human creature as creator (or 'co-creator' as some have suggested) who contributes to the divine work of creation through new technology remains an open question, more urgent than ever. Some people of religious conviction see science as a new source of theology and technology as a new avenue of service in the grand work of creation" (Cole-Turner 2009, 198). That Cole-Turner himself may well be one of those 'people' he refers to, appears likely from his stating elsewhere that "we humans do play something of a cooperative role in the creative process and... we should intend to do so", though he does immediately add "Before we can dignify this role with the label of 'co-creation', however, we need to have a clear idea of what the creator intends for the creation" $(1987,345)$.

He goes on to quote approvingly Prof Arthur Peacocke, a scientist and Christian apologist who suggests that we are "co-explorers" with God. Cole-Turner then suggests, "We might be that part of creation through whom God works to explore new possibilities as yet unknown to God" $(1987,348)$. In his enthusiasm 
to give an apparently unshackled theological mandate for scientific advance, he does not even seem to consider the possibility that a God who doesn't know something that his creatures know, might not be God at all.

To be fair to Cole-Turner however, he does clearly acknowledge in a more pastorally-oriented reflection, that the hubris of unbridled confidence in scientific progress is not without its dangers. His point is not that we merely "exaggerate these technologies' powers or the speed of their development, but that by exaggerating them we distort the limited but legitimate value of the technologies. They become a dangerous obsession under which our anxieties flourish. Thinking we are on track for a technology that can control life, we run the risk of losing whatever small capacity we have to live at peace with our uncontrolled imperfections, with illness and disability" (Cole-Turner 2002, 44).

It is indeed a difficult path to tread between on the one hand realising the hope of healing of disease resulting from the ethical application of new genome editing technologies and on the other hand, falling into the danger of thinking that we can become masters of our own destiny entirely without God

\section{Genes Are Us?}

Christian theology in common with many other world faiths, contends that we are more than the sum of our constituent parts, including our DNA base pairs. However it is not perhaps surprising that by contrast, scientists have often given the impression that we are determined by our genes in a very mechanistic way. Francis Crick and James Watson, the discoverers of DNA structure, themselves subscribe to this view. Crick dubbed it The Astonishing Hypothesis - "that "You", your joys and your sorrows, your memories and your ambitions, your sense of identity and free will, are in fact no more than the behaviour of a vast assembly of nerve cells and their associated molecules" (Crick 1994,3 italics mine).

As we have seen, thought differing in significant ways, both the Augustinian and Irenaean views of the Fall agree it involves the exercise of free will. The advent of genetic determinism is not the first challenge to the reality of free will that science has presented however and the type of 'knight's move' involved in every case is exemplified in Crick's use in the quote above of the phrase 'no more than'. Certainly the 'nerve cells and their associated molecules' including those in DNA are necessary, but are they sufficient for all that Crick attributes to them, such as our ambitions? 


\section{Cybernetic Determinism}

The 'smoke and mirrors' intrinsic to Crick's approach is magnificently exposed in another context by Hans Jonas' in his 1966 essay on 'Cybernetics and human purpose'. Norbert Weiner first defined cybernetics in its modern sense in 1948 as "the science of communication and control in the animal and the machine" (Weiner 1948, 6); he proposed, "Society can only be understood through a study of the messages and communication facilities which belong to it" (Weiner 1950). Jonas seeks to demonstrate that the claim of cyberneticists that purpose and teleology can be evolved from mechanical premises alone is "spurious and mainly verbal" $(1966,111)$. He does so by arguing that the cyberneticists mistake 'carrying out a purpose' for 'having a purpose'. Machines may (and do) carry out purposes but the purposes they carry out are human purposes.

At the conclusion of his detailed argument, Jonas turns to biology. He suggests that though at a superficial level, the sensory-motor pattern of behaviour in animals does resemble a feedback loop in a machine, it is in fact entirely different because living beings are creatures of need. "This basic self-concern of all life, in which necessity and will are bound together, manifests itself on the level of animality as appetite, fear and all the rest of the emotions. The pang of hunger, the passion of the chase, the fury of combat, the anguish of flight, the lure of love - these and not the data transmitted by the receptors...make behaviour purposive" (Jonas 1966, 126).

To have purpose, a goal, a telos requires more than mere input and output. Jonas' conclusion is still strikingly relevant today in an age of genomic reductionism - "According to cybernetics, society is a communication network for transmitting, exchanging and pooling of information and it is this that holds it together. No emptier notion of society has ever been propounded. Nothing is said on what the information is about and why it should be relevant to have it" (Jonas 1966: 126).

\section{Genetic Determinism}

A similar problem occurs in relation to the reductionist view of the transmitting, exchanging and pooling of genetic information. It is fascinating to read in literature published before the mapping of human genome, how the concept of the gene defined as 'a unit of heredity containing the information for one protein' became known as the central dogma of molecular biology (Suzuki and Knudtson 1989, 52). At a CIBA symposium in 1989, one senior scientist working on genome mapping stated that "Genetics investigates the plan of the organism. The plan is embodied in the collection of genes that is handed down in the germ line to specify the construction of the organism ....The manifesto - if 
not the programme - of molecular genetics must remain the computation of organisms from their DNA sequences" (Cited in Jockemsen 1997, 77).

With this kind of outlook, it is easy to see how genetic determinism as expressed by Crick above can take root. But even prior to human genome mapping, there was evidence that the relationship of the structure of a particular protein and the structure of a particular organ, let alone an entire organism, is not a direct one (Tauber and Sarkar 1992). Jockemsen points out two other epistemological problems of the genetic determinist view of a direct causal relation between gene and trait. Firstly this view elides two very different types of knowledge - the molecular biological knowledge with the knowledge involved in recognition and judgement of clinical diagnosis. He makes the important point that observation of the correlation between gene defects and clinical diagnostic features does not prove genes are causally related to traits. "It only proves that gene defects can disturb the development of the organism. The gene or gene defect acquires meaning only in the context of the existence and functioning of the entire organism. In other words, the observation that concrete genetic information is a necessary precondition does not make that information a sufficient precondition for a 'normal' development." (Jockemsen 1997, 79). Secondly, if the DNA sequence contains a message, this presupposes a meaning in the message which cannot be generated by the mechanism which translates it. Furthermore the DNA has not generated the translation mechanism since in order to be expressed it needs that mechanism. The genetic message itself "needs an explanation - both a final and causal one" (Jockemsen 1997:79) and for people of the Abrahamic faiths, that final cause is God.

If this were not enough in itself, new developments have given rise for even more reasons to be cautious about genetic determinism. Before the HGP, it was thought that there were around 80 ooo coding genes for proteins. When the actual number turned out to be around 25 ooo, the rest of the DNA was initially written off as redundant and labelled as 'junk' (Parrington 2016, 72). However, the publication in 2012 of the Encyclopaedia of DNA Elements (ENCODE) project soon changed that. ENCODE (2012) demonstrated that $80 \%$ of the DNA has newly recognised biochemical functions (Parrington 2016, 91), many of which of are carried out non-coding RNAs (ncRNAs) which are involved in regulation of protein coding genes by either facilitating or down-regulating their expression. There is also evidence that these ncRNAs and their effects are influenced by environmental factors including smoking (Hou et al 2011). So with both a) the vast majority of the DNA not coding for proteins and b) environmental factors influencing the ncRNAs' control of protein- coding, the central dogma of molecular biology looks less and less central than it did. 
This is even without taking into account epigenetic effects. The term epigenetics has had various definitions. Perhaps the simplest to understand is "the study of mitotically and/or meiotically heritable changes in gene function that cannot be explained by changes in DNA sequence" (Riggs and Porter 1996, 29). However this definition has recently been refined in both more positive and comprehensive terms defining epigenetic events as "the structural adaptation of chromosomal regions so as to register, signal or perpetuate altered activity states" (Bird 2007, 398).

The key point to grasp is that changes to the DNA other than the widely known mutations of DNA sequencing, can influence changes in the organism, some of which are inheritable. These changes may entail small molecules being added to or removed from both the DNA itself and/or the histone complexes, around which the nucleic acid sequences are spiraled. Environmental factors can also affect these epigenetic changes.

Finally even for those genes that do code for a single protein, recent findings have shown that the protein is not all there is to the expression of that gene. The gene for enzyme monoamine oxidase A (MAOIA) provides perhaps the best-known example. This enzyme inactivates neurotransmitters such as serotonin, which therefore accumulate when the gene for MAOA is defective. A Dutch study (Brunner et al 1993) of a family in which male members exhibited aggressive behaviour showed that using DNA mapping that the gene for MAOA had mutated and the resulting enzyme was ineffective so neurotransmitter levels were much higher than normal in these men. Women were unaffected because the gene is sex linked. However another study (Caspi et al 2002) examined another gene variant known as MOAO-L that produces a low functioning rather than non-functioning enzyme variant. Caspi's team followed up abused children over many years and found that presence of MOAO-L alone was not associated with high levels of aggression over 25 years, unless the children had been subject to maltreatment themselves. In contrast, those children with a normal MOAO gene appeared more resistant to developing aggressive behaviour even if they were subject to childhood abuse. In short, MOAO research to date suggests that the idea of mutation leading inexorably to phenotypic change is rarely, if ever, all there is to human behaviour.

Where does this then leave us theologically in relation to our human responsibility before God? It surely confirms that though our genes do influence everything about us, they do not determine everything we do. Our environment and our human wills also have a large part to play in what we do with our lives. "Our whole being is influenced by our genes. But not everything about us is explained by our genes. Environment and personal responsibility play a role. Theology has a stake in maintaining that the role played by personal 
responsibility is genuine and significant. It is not epiphenomenal or illusory" (Cole-Turner 1992, 170)

\section{The Secular Soul and Two Types of Telos}

What is illusory is to place all our hopes in our genes "fueling the expectation that the last word about the human genome will be last word about human nature" (Mauron 2001). In an article critiquing the popular rise of the concept of the genome as the 'secular soul', Prof Alex Mauron writes, "the notion that our genome is synonymous with our humanness is gaining strength. This view is a kind of "genomic metaphysics": the genome is viewed as the core of our nature, determining both our individuality and our species identity. According to this view, the genome is seen as the true essence of human nature, with external influences considered as accidental event" (Mauron 2001).

His article surely raises the question of whether the concept of the soul as a metaphor for the genome might also indicate the religious element of the quest to map and explore it. Demonstrating the inadequacies of genetic reductionism does not go far enough in a critique of it in that it does not consider the reasons why this reductionism has gained such a hold. Its historical roots may go back to the seventeenth century when earlier ideas of human knowledge as largely passive and received by illumination or rumination, began to wane. What is now termed a constructionist epistemology then began to emerge where knowledge is constructed by measurement of and experimentation with the world. In his seminal work on this paradigm shift, Funkenstein comments, "applying knowledge-through-construction to the whole world was as inevitable as it was dangerous. It was dangerous because it makes mankind to be 'like God knowing good and evil' " $(1986,290)$, - echoing the language of ancient Augustinian Fall.

Prof Robert Song powerfully points out that the Human Genome Project is a game-changer in the search for eliminating human suffering. At the same time as it provides knowledge of how the body is constructed, it also shows how it might be reconstructed. He suggests the HGP has become " a surrogate form of salvation, ..... It develops, for example, a doctrine of creation, which conceives nature as a raw material available for technological manipulation, while its anthropology defines human beings in terms of self-defining freedom above the contingencies of bodily life. It espouses eschatological hope, which lies in the dream of escape from finitude and locates the means of salvation to that end in the application of technical reason..." (Song 2003, 178-79). 


\section{Divergent Paths of Purpose}

Whilst of course there are some overlaps of this alternative secular creation narrative with a Christian understanding of human stewardship and authority over the rest of nature, it is the means of reaching its telos or end purpose which makes the secular vision very different from the Christian vision revealed in scripture and indeed I would suggest sets the two completely at odds with other.

In an illuminating paper on how human potential relates to genetics and Christian theology, Lysaught makes reference to the seventeenth century paradigm shift considered above, in pointing out that that post-Enlightenment humanistic progress and Christian theology are both teleological and the intended goal in both is towards a future of wholeness and completion. However "in the narrative of genetic potential, the future utopia is achieved by the temporal eradication of human imperfection. In the scriptural vision-instantiated in Eden, the promised land, occasionally in Jerusalem, the kingdom of God, the heavenly banquet, and the new creation-communal human flourishing is achieved simply when individuals and communities choose to dwell with God. They might still be fat, not very smart, short, slow runners, or manifest myriad other flaws, but when persons in Scripture choose to acknowledge God's power and to live as God's people, perfection, wholeness, goodness (holiness, righteousness, and justice) come to be. The definition of human perfection in Scripture is not perfection of mind or body but rather: being in relationship with God" (Lysaught 2011, 235).

Moreover, contrary to popular and persistent myths about Christianity, it is not the perfect whom Christ calls to be his people but rather those who acknowledge their sickness (Matthew 9v12; Mark 2v17; Luke 5v31). "God chose the foolish things of the world to shame the wise; God chose the weak things of the world to shame the strong. God chose the lowly things of this world and the despised things — and the things that are not—-to nullify the things that are" (I Corinthians 1 v27-28).

\section{Conclusions}

In deciding if various aspects of genome editing are ethical from a Christian perspective, there are many factors to consider. Does it increase the ability to view life as a gift to be received with thanks or a commodity to be grasped as a right? Does it acknowledge human nature as something to be restored to wholeness or something to be transcended by enhancement? Does it recognise the limitations of its likelihood of success in changing phenotype predict- 
ably as it discovers the increasing importance of environmental factors and the complexity of epigenetic mechanisms? What is the telos of the genome editing project and perhaps most crucially of all does it reflect wise stewardship and care for the world as creatures made in the image of God or does it seek to enable us to become as God in recreating ourselves into something else?

\section{References}

Brunner H G, Nelen M, Breakefield X O, Ropers H, van Oost B A. 1993. "Abnormal behavior associated with a point mutation in the structural gene for monoamine oxidase A". Science 262: 578-80

Bonhoeffer, Dietrich. 1937. Creation and Fall (English translation 1959). London: SCM Press

Boorse, Christopher. 1976. "What a theory of Mental Health should be". Journal for the Theory of Social Behaviour 6: 61-84

Callahan, Daniel. 1973. "The WHO definition of Health". Hastings Centre Studies 1.3: 7787

Cann, Rebecca L., Mark Stoneking, and Allan C Wilson. 1987. "Mitochondrial DNA and Human Evolution". Nature 325:31-36.

Caspi, Avshalom. Joseph McClay, Terrie E. Moffitt, Jonathan Mill, Judy Martin, Ian W. Craig, Alan Taylor, and Richie Poulton. 2002. "Role of genotype in the cycle of violence in maltreated children". Science 297: 851-854

Cole-Turner, Ronald S. 2009. "Synthetic biology; Theological Questions in Biological Engineering". In Without Nature?: A New Condition for Theology, edited by Albertson D, King C, 136-152. Fordham University Press

Cole-Turner, Ronald S. 2002. "Biotechnology: A Pastoral Reflection". Theology Today 59: 41-54

Cole Turner, Ronald S. 1992. "Religion and Human Genome". Journal of Religion and Health 31: 161-173

Cole-Turner, Ronald S. 1987. “Is Genetic Engineering Co-Creation?". Theology Today 44: 338-349

Crick, Francis. 1994. "The Astonishing Hypothesis". New York: Simon and Schuster

ENCODE Project Consortium. 2012. "An integrated encyclopedia of DNA elements in the human genome". Nature 489: 57-74

Funkenstein, Amos. 1986. Theology and the Scientific Imagination from the Middle Ages to the Seventeenth Century. New Jersey: Princeton University Press

Hare, Richard M. 1986. "Health". Journal of Medical Ethics 12: 174-181

Hou, Lifang. Dong Wang, and Andrea Baccarelli. 2011. "Environmental chemical and microRNAs". Mutation Research 714: 105-112 
Irenaeus, (c18o) Against Heresies http://www.newadvent.org/fathers/o1o3.htm

Jockemsen, Henk. 1997. "Reducing People to Genetics". In Genetic Ethics: Do the Ends Justify the Genes?, edited by John Fredric Kilner, Rebecca Davis Pentz, Frank E Young. 75-83. Milton Keynes: Paternoster Press

Jonas, Hans. 1966. "Cybernetics and Purpose: A Critique". In The Phenomenon of Life, edited by Vogel, L and H Jonas (2000), 108-134. Westport Connecticut: Greenwood Press

Junker-Kenny, Margaret. 2003. "Genes and the Self: Anthropological questions in the Human Genome Project" In Brave New World: theology, ethics and the human genome edited by Celia Deane-Drummond, 116-140. London: T and T Clark

Lysaught, M Therese. 2011. "The Last Shall Be First: Human Potential in Genetic and Theological Perspectives". Theology and Science, 9: 223-240

Messer, Neal. 2011. Respecting Life: Theology and Bioethics. London: SCM Press

Messer, Neal. 2003. "HGP, Health and the "Tyranny of Normality". In Brave New World: theology, ethics and the human genome, edited by Celia Deane-Drummond, 91-115. London: $\mathrm{T}$ and T Clark

Mauron, Alex. 2001. "Is the genome the secular equivalent of the soul?" Science 291: 831-832 DOI: $10.1126 /$ science. 1058768

New Advent. 2017. "Against Heresies (Book IV, Chapter 11)". Accessed from http://www. newadvent.org/fathers/o103411.htm

New Advent. 2017. “Against Heresies (Book IV, Chapter 38)”. Accessed from http://www. newadvent.org/fathers/o103438.htm

O'Connell S. 2009. “Are human beings impossible to ape?" Daily Telegraph. Accessed 3o.6.20o9 http://www.telegraph.co.uk/news/science/evolution/5695045/Are-human-beings-impossible-to-ape.html

Page Ruth. 2003. "The Human Genome and the Image of God". In Brave New World: theology, ethics and the human genome, edited by Celia Deane-Drummond, 68-85. London: $\mathrm{T}$ and T Clark

Parrington, John. 2016. The Deeper Genome: why there is more to the human genome than meets the eye. Oxford: Oxford University Press

Ramsey, Paul. 1970. Fabricated Man: The Ethics of Genetic Control. New Haven: Yale University Press

Riggs, Arthur D. and Thomas N. Porter T. 1996. "Overview of epigenetic mechanisms". In Epigenetic mechanisms of gene regulation, edited by Russo VEA, Martienssen R, Riggs AD, 29-45. Cold Spring Harbor, NY: Cold Spring Harbor Laboratory Press

Russo, Vincenzo E. A., Robert A. Martienssen, and Arthur D. Riggs, (eds). 1996. Epigenetic Mechanisms of Gene Regulation. Woodbury: Cold Spring Harbor Laboratory Press

Schneider, John. 2012. "The Fall of Augustinian Adam: Original Fragility and Supralapsarian Purpose". Zygon 47: 949-969

Seller, Mary J. 2003. "Genes, Genetics and the Human Genome". In Brave New World: 
theology, ethics and the human genome. edited by Celia Deane-Drummond, 27-44 . London: $\mathrm{T}$ and T Clark

Song, Robert. 2003. "HGP as Soteriological Project". In Brave New World: theology, ethics and the human genome, edited by Celia Deane-Drummond, 164-184. London: T and T Clark

Suzuki D, Knudtson P. 1989. “Genetics”. Cambridge, Massachusetts: Harvard University Press

Tauber, Alfred I., Sahtora Sarkar. 1992. "The Human Genome Project: Has Blind Reductionism gone too far?". Perspec Biol Med 35:220-35

Weiner, Norbert. 1950. The Human Use of Human Beings. Cambridge, Massachusetts: Da Capo Press

Weiner, Norbert. 1948. Cybernetics: Or Control and Communication in the Animal and the Machine. Cambridge, Massachusetts: MIT Press

World Health Organisation. 1948. http://www.who.int/about/definition/en/print.html Wyatt, John. 2009. Matters of Life and Death; Human Dilemmas in the light of the Christian Faith. London: Leicester IVP 